\title{
Appreciation of the Chemical Ingredients of Black Grapes Structures Vitis vinifera L. and Identify the Impact Against oxidation
}

\section{Ashraq Monir Mohamed, Hind Kamal Ali, Nidal Mohamed Saleh}

Department of food science, Agriculture of collage, University of Baghdad, Iraq

Correspondence Author: Ashraq Monir Mohamed, Department of food science, Agriculture of collage University of Baghdad

Received date: 23February 2018, Accepted date: 23April 2018, Online date: 28April 2018

Copyright: (C) 2018 Ashraq Monir Mohamed et al. This is an open-access article distributed under the terms of the Creative Commons Attribution License, which permits unrestricted use, distribution, and reproduction in any medium, provided the original author and source are credited.

\section{Abstract}

You had estimated the chemical composition of grape Vitis vinifera L. black structures and humidity were 10.65 and $8.04 \%$ and protein 5.63 and $5.87 \%$ and carbs $80.4382 .21 \%$ fat ratio and 0.36 and $0.39 \%$ And ash 2.93 and $3.49 \%$ and 60.72 fibers and $67.83 \%$ respectively. Phenols also estimated flavonoid, broanthosianidin ratio was $87.7 \%$, $92 \%$ and $7.5 \%$ respectively. Alcohol extraction process was conducted for the Structures of black grapes as well as testing the Effect of extracted antireductionist us anti oxidation and iron binding force.

Key words: grapes structures Vitis vinifera L., Antioxidant, chemical composition of grape

\section{INTRODUCTION}

Natural compounds in fruits and vegetables, spices and Traditional medicinal plants play traditional preventive against many diseases caused by oxidation and microscopic Biology of infection [17]. These simple and complex phenols ingredients and compounds that contain sulfur and the phenol compounds had large aspect of attention to what its from The importance of reducing risk in dead from diseases including allergies and diseases caused by microorganisms [3,8]. Natural antioxidant won In the plants used as food so much attention because of the tathermdadat of industrial health side as well as antioxidants that some physical qualities such as unacceptable Thbatitha in general temperature and volatility [29]. Given that the diet is a source of antioxidants that help protect the body from damage Caused by free radicals, And prove that plants that contain flavonoids compounds possess powerful antioxidants properties [5]. Since he found it working on the consistency of the food by delaying and impeding the Rancidity phenomenon and prolong shelf life [7] believes that oxidative stress for fat factor However in the progression of atherosclerosis [10].

A number of studies have demonstrated that flavonoideh like (Qurecetin) is the main contributor to antioxidant activity [18] grape seed is Castanascatichen hand sources Catechin) and abikatekyen (EC) and soldering acid Gallic and broanthosianid and is suitable for the production of raw materials Food antioxidants Faria et al, [13] is one of the richest grape fruits and most beneficial and profitable, and that his active role in body building and repairing tissues evaluated and treat many diseases and illnesses as well as.

The possibility of eating it year round in mushy or dried, and grape fruits a Fast digestion with high nutritional value, and his aptitude for calculating representation during any body. Hammer [14].

The role of phenolic compounds in inhibiting oxidation (Low Density Lipo Protein) within the living body through extraction of Catechin compounds (Catechin, Procyanidin).

Addictions types (B8, B6 and B4 and B3 and B1) and isolation and purification of grape seed, and found that all of the Catechin (C) and white Catechin (EC) possessing the highest effective antioxidant, and vehicles Gallic acid-like Singularity and alkorstin (Quircetin) and Caffeic acid and Rutin routine), a group of vehicles that contain B6 and Ellagic acid her low effectiveness against oxidation. And containing Peeling grapes to large quantities of flavonoids as well as on other vehicles multiple Alvin and so with the red and white grapes, soy and other [16].

Grape structures represent remnants of food processing can be utilized in several areas, so the research was conducted to study the chemical composition of the main components of grape black intensity structures as well as efficient vehicles and estimate asses its effectiveness as antioxidants.

\section{Collecting samples:}

\section{MATERIALS AND METHODS}

We choose sample of grape Grove was located in the alsragi / Balad / Salahuddin province during the trial period of the season. Hull is separated from the seed and pulp were washed with tap water and then dried up by electric furnace with the temperature of $40 \mathrm{~m}$ and kept in opaque boxes inside the refrigerator at temperatures $8 \mathrm{~m}$ until use.

Assess the key components of the structures of black grapes Vitis vinifera L.:

Estimation of humidity: estimated percentage of moisture as contained in A.A.C.C. [1]

Estimation of protein:total protein form a way Kjeldhal [2].

Estimating fats: followed A.A.C.C. (9 estimating fatty substances in your soxcilat with ether).

Estimate the percentage of ash: just ash estimated standard contained in the A.O.A.C. A.A.C.C. [1]

The proportion of fiber: estimated by the method used by Delaly and Alhakim [12]

Estimate the carbohydrate compounds: estimated by the method described by Delaly and Alhakim [12]. 


\section{Extraction:}

\section{MATERIALS AND METHODS}

Blending 10 grams of powdered black grapes structures with $50 \mathrm{~m}$ of ethyl acetate solution and distilled water by 10:90 in the flask and close the jug and then leave 24 hours to the magnetic vibrator, then nominated filter paper (1 No What then put the extracted in the Suppression of separation and process repeated added $\mathrm{HCH}$ four times with $25 \mathrm{ml}$ each time to separate the oil from Catechin, gallic mixture containing nominated during the nomination paper containing sodium sulfate anhydrous $\mathrm{Na} 2 \mathrm{SO} 4$ ), and focused evaporator rotor temperature of $40 \mathrm{~m}$ drying oven was remaining electrical extraction temperature of $40 \mathrm{~m}$ [22] and re t ramp add $5 \mathrm{ml}$ distilled water, sterilize present nomination papers to extract maikrobiologih 0.45 micrometre aperture.

Quantification of some active ingredients in grape structures:

The measuring curve was prepared for each of the phenol broanthosaindin the adoption of standard vehicles Gallicacid, Catechin, Proanthocyandin from the order as shown in figures $1,2,3$ the same order too. He held the quantification of three active ingredients as follows:

\section{1-Estimate of total phenols:}

Folin -ciocalteu fallen detector method adopted by adding $2.5 \mathrm{ml}$ to $0.5 \mathrm{ml}$ (grape structure) extract $(1 \mathrm{mg} / \mathrm{ml}$ ), with the addition of $2 \mathrm{ml}$ sodium carbonate $\mathrm{Na} 2 \mathrm{Co} 37.5 \%$. Then leave the mixture 30 minutes at room temperature and then measured the absorbency 760 nanometer wavelength and calculate the amount of total phenols adoption curve measurement of gallic acid [6] (Figure 1).

\section{Assessment of flavonoids:}

Been mixing $1 \mathrm{ml}$ extract grape structures $(1 \mathrm{mg} / \mathrm{ml})$ with $5 \mathrm{ml}$ distilled water, then add to mixture $0.3 \mathrm{ml}$ solution NaNo2) $5 \%$ ) After $5 \mathrm{minutes}$, add $0.6 \mathrm{ml}$ lotion Alc13 (5\%, After five more minutes, add $2 \mathrm{ml}$ sodium hydroxide $\mathrm{NaOH}$ and complete the volume to $10 \mathrm{ml}$ (volumetric), then measured the absorbency wavelength 510 nanometers. And estimated amount of flavonoids by adopting the standard curve Catechin (Figure 2) [25].

\section{Broanthosianidin assessment:}

Melt $1 \mathrm{mg}$ grape structures extract powder $1 \mathrm{ml}$ Methyle alcohol with add $9 \mathrm{ml}$ reagent alvanlin and put on the mixer for 10 seconds then put in the incubator at $19-21 \rho^{\circ}$ and after 15 minutes measured absorbency the wavelength 500 nanomitrotm quantification of surrogate broanthosianidin adoption curve measurement for compound record for this compound [11].

\section{Anti oxidant effect estimation:}

1. Portability - Chelating ability:

In accordance with the method described by Su et al [28] uses abstract in different starting 10 to $50 \mathrm{mg} / \mathrm{ml}$ mixing $1 \mathrm{ml}$ of each concentration with $0.2 \mathrm{ml}$ iron chloride (mM2) and then add $0.2 \mathrm{ml}$ Hydroxy compound quinoline-8 Instead of $5 \mathrm{mM}$ (Ferrozine) and leave the mixture at room temperature $10 \mathrm{minutes}$ then all tested concentrations measured the absorbency wavelength nanometers 562, Spur gearbox, susceptibility of Ascorbic acid to bind the ferrous ion by adopting a reference for comparison according to the following equation:

$$
\text { Competence the Union\% }=1-\left(\frac{\text { Read the absorbency of the form }}{\text { Read the absorbency to control sample }}\right) \times 100
$$

\section{Measure the reductionist force to extract:}

Followed the method described [9]. She attended concentrations extracted from $(2,4,6,8,10)$ and mix $1 \mathrm{ml}$ of extract $2.5 \mathrm{ml}$ potassium cyanide Potassium cyanide Ferric iron (1\%), ' $2.5 \mathrm{ml}$ of daraei phosphate ( $\mathrm{PH} 6.6,0.2 \mathrm{M})$ and put the mixture in the incubator $50 \mathrm{c}^{\circ}$ for 20 minutes, then add the unzipped Trichloroaceticard (TCA)) $1 \%$ for the purpose of stopping the interaction and then centrifuged at rpm3000 for 10 minutes, ignore the deposit, and added to lucid 1 $\mathrm{ml}$ ferric chloride $1 \%$ and leave for 10 minutes. Measured absorption coefficient to 700 nanometers and adopted industrial antioxidant BHT as a reference for comparison.

\section{RESULTS AND DISCUSSION}

Analysis of the basic components of grape structures (black intensity) found that the percentage of moisture was $10.65 \%$ protein was 0.415 percent. Either your carbs by $1956 \%$, Are carbohydrates important nutrients for their sugars and their derivatives such as cellulose and pectine materials being the source Foundation in thermal power body processing, And fat were estimated using Petroleum ether petroleum ether), the ratio was $1.31 \%$. and the estimated percentage of ash were $1.8 \%$ and estimated proportion of fibers and amounted to $60.72 \%$. table (1). And the proportions were similar with most updated Al-samraee (2011).

Table 1: Percentages of key ingredients for black grape structures.

\begin{tabular}{|l|l|l|}
\hline Sn & Base component & Percentage\% Structures of black grapes \\
\hline 1. & Moisture & $\mathbf{1 0 . 9 5}$ \\
\hline 2. & Crud Protein & $\mathbf{0 . 4 1 5}$ \\
\hline 3. & Fat & $\mathbf{1 . 3 1}$ \\
\hline 4. & Total Carbohydrate & $\mathbf{1 . 9 5 6}$ \\
\hline 5. & Ash & $\mathbf{1 . 8}$ \\
\hline 6. & Crud Fiber & $\mathbf{6 0 . 7 2}$ \\
\hline
\end{tabular}

Table 2 focus of some active ingredients in grape extract of the biological structures of diverse events, the ratio of $87.7 \%$ amounted to phenols adoption curve Gallic acid standard form (1) recalling the high content of these compounds in grape structures. This leads to pause for thought in making use of these plant residues of phenolic compounds and recent content role in many events can be exploited in various areas of medicine or feeding animals, food preservation, especially when compared to obtained from phenol in waste with other plants or food products, higher content of phenols in grape plant content reflects the structures of plant phenols phenolic acids include flavonoidat simple, as well as several other phenols other phenolic compounds show totals hydroxyl group linked to hydrocarbon mechanistic aspects [20]. [15].

Recent studies have shown a number of plant products include multiple tanins like flavonoids and various plants and herbal extracts shown do antioxidant

Flavonoids ratio was $29 \%$, depending on the composition of Catechin standard form (2) it is also a good percentage of these structures effective ingredients content it represents one third of the phenol content of the structures

Boat with presenting her findings to Salih AL-Janabiet [19]. Walflavonoidat well its role of biological multi [26] broanthosianid ratio was 7.5\%, and estimated amount of broanthosianidin based on standard broanthocyanidin compound shape (3) this compound increased interest in looking for sources that contain what has many biological events. As still effective ingredients containing ratios structures we can say high benefit drawn from them for the purpose of this cheap and renewable source for such important components, broathtosianidin is high in concentrations of grape skin (peeling grapes) and grape seed, lemon tree weklv Gulf Pine pineapple and Cranberries and Hazel nut tree leaves and two of the most well known sources and more sources beach and the richest known sources of grape seed extract passes weklv[23]. 
Citation: Ashraq Monir Mohamed, et al., 2018. Appreciation of the Chemical Ingredients of Black Grapes Structures Vitisvinifera L. and Identify the Impact Againstoxidation. Advances in Environmental Biology., 12(6): 4-8.

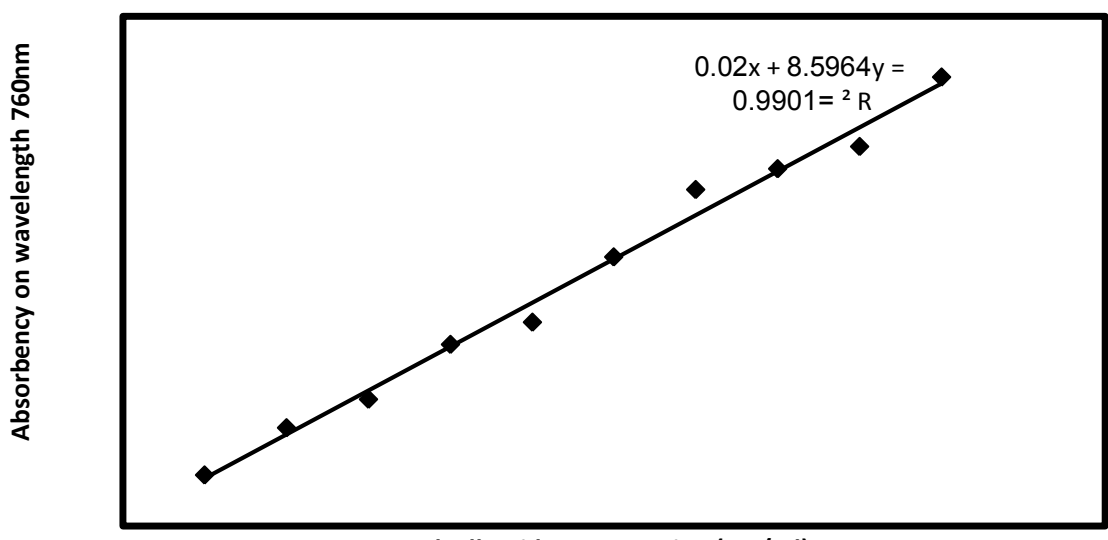

Algalk acid concentration $(\mathrm{mg} / \mathrm{ml})$

Fig. 1: Standard curve for Gallic acid.

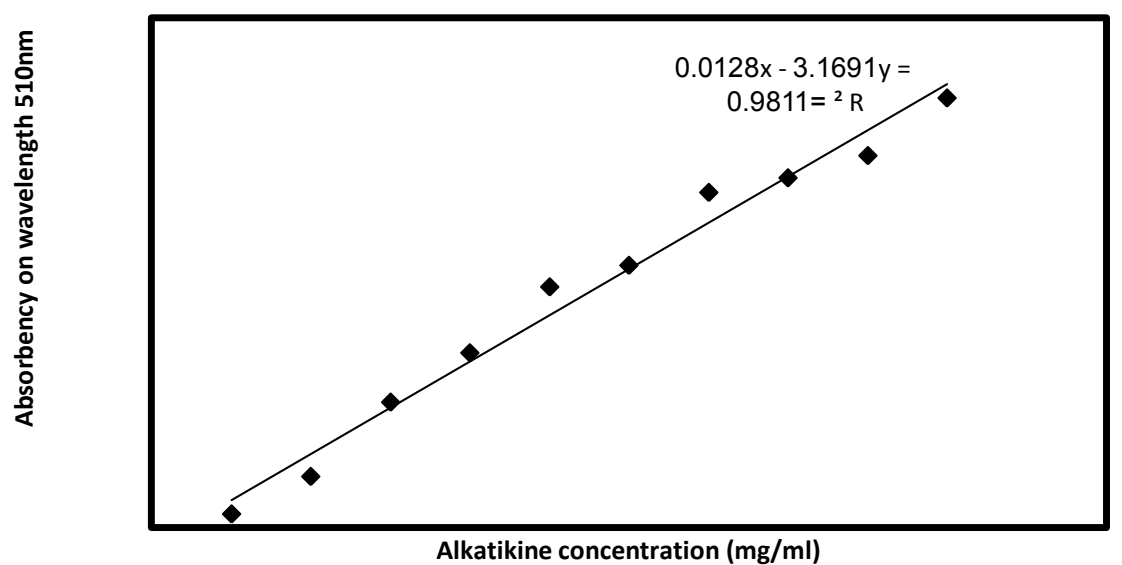

Fig. 2: Standard curve Catechin

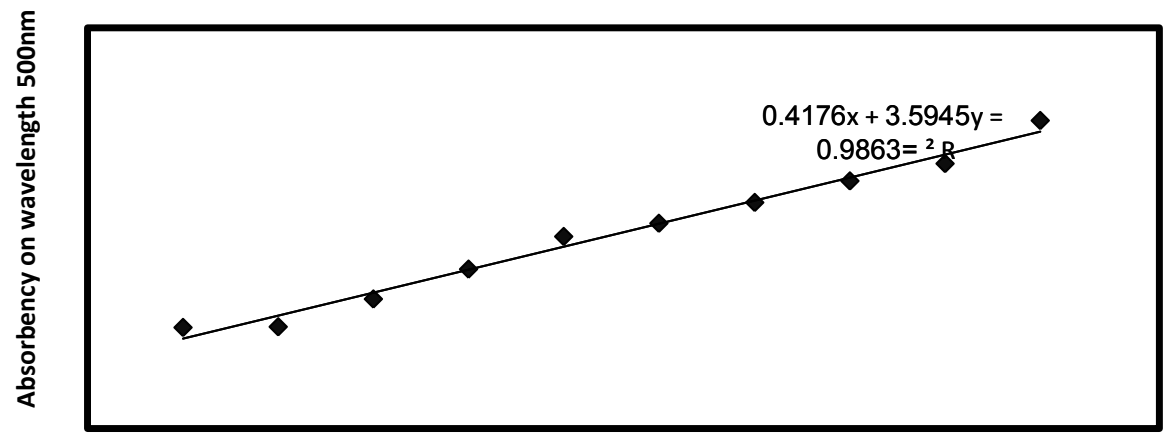

broanthosianidin concentration $(\mathrm{mg} / \mathrm{ml})$

Fig. 3: Standard curve broanthosianidin. 
Citation: Ashraq Monir Mohamed, et al., 2018. Appreciation of the Chemical Ingredients of Black Grapes Structures Vitisvinifera L. and Identify the Impact Againstoxidation. Advances in Environmental Biology., 12(6): 4-8.

Table 2: Quantitative detection of active compounds in the extract of black grapes structures.

\begin{tabular}{|l|l|}
\hline Detect & Percentage of boat in abstract \\
\hline Phenols & $\% 87.70$ \\
\hline Flavonoids & $\% 29$ \\
\hline broanthosianidin & $\% 7.50$ \\
\hline
\end{tabular}

Figure 4 shows the effectiveness of antioxidants to ferrous ion binding capability to extract grape structures compared with BHT graduated to effectively Spur gearbox, to $25.3 \%$ from the lowest concentration $(10 \mathrm{~mm} / \mathrm{ml})$ at $102.9 \%$ at the highest concentration was selected $(50 \mathrm{mg} / \mathrm{ml})$, either industrial antioxidant BHT connectivity gave higher than only abstract when the last three concentrations $50,40,30 \mathrm{mg} / \mathrm{ml}$, if susceptibility to anti- $84.66 \%$, $110.00 \%$, while the corresponding order 135.56 interconnectivity extracted when the same last three concentrations by $87.5 \% 79.4 \%$ sequence, $102.9 \%$ Note the increase among the majority of the few abstract and BHT with increased susceptibility to increased concentrations. But at minimum, final laboratory focus followed by opening the same form of connectivity were higher for abstract of BHT phenolic compounds may return to diversity and proportionally affected comparability and mechanisms that are owned as antioxidants. factors are important in terms of rancidity fat in food and iron stimulates interaction During the show the peroxides types of structures for other different concentrations or grapes varieties that demonstrated by other studies and geographical distribution and the biological effectiveness and effective vehicles vary depending on varieties and seasons, Pantelidis et al [21].

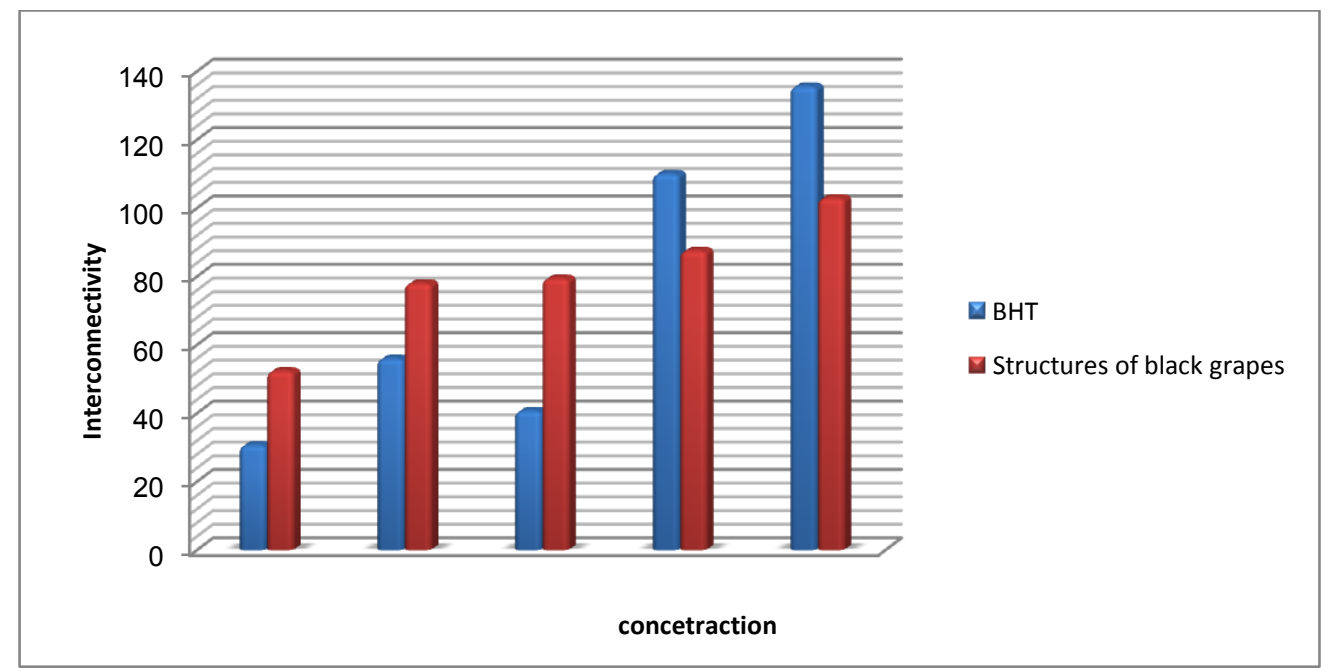

Fig. 4: Black grapes structures extract portability to connect ion.

Iron compared with BHT:

Effective mechanisms or mechanics back antioxidant compounds, including estimating the reductionist force according to the results shown in figure (5) clear difference between search and extract Ascorbic acid the latter is strongly reductionist overtook about abstract and all concentrations are chosen. Reductionist force amounted to $13.9 \%$ and Ascorbic acid extracted, $30.65 \%$ respectively at the lower concentration $(2 \% \mathrm{mg} / \mathrm{ml})$ while to $21.4 \%, 88.53 \%$ respectively when the Supreme focus Lab $(10 \mathrm{mg} / \mathrm{ml})$ indicate the strength-giving compounds reductionist electrons, and act as antioxidants secondary raw and secondary sorts of antioxidants are able to break the chain of free radicals within $2 \mathrm{hrs}$ to hydrogen atoms Shimada et al., [27]. While branthosianidi compound extracted from the leaves and stalks and joints and soft Fine roots from a plant Grevillearobusta, Effective higher antioxidant Ascorbic acid and BHA industrial measuring antioxidant mechanism as the roots. You may even cause portability curb free radicals to weakened effectiveness varied readings antioxidant extract applicable methods (procedures) sufficient capacity for broanthosianin compound and its effects the health beneficial defensive already from cardiovascular and curb the free radicals.

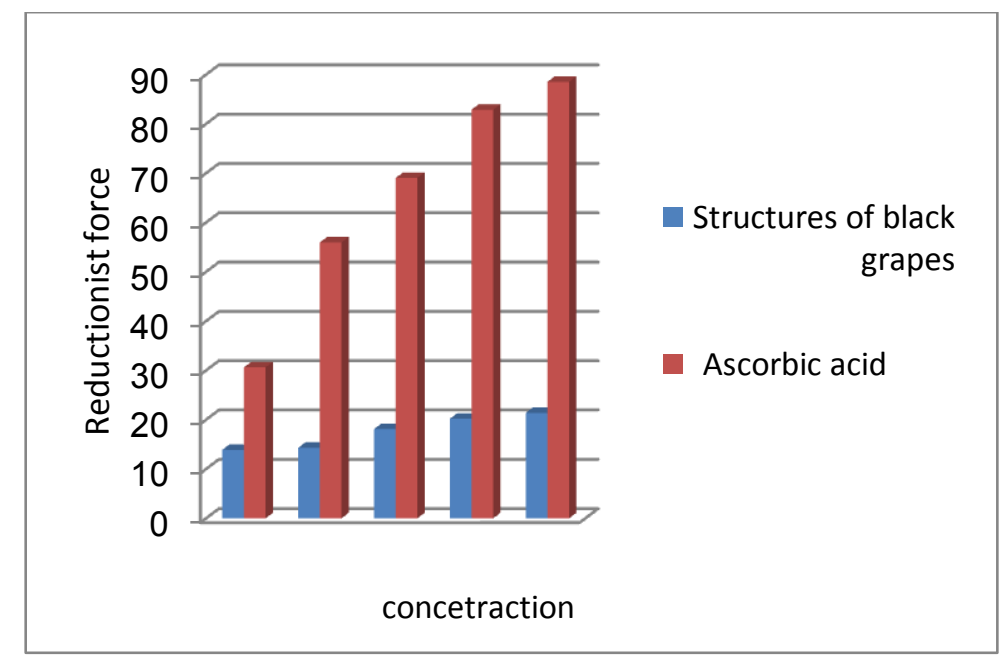

Fig. 5: Reductionist force to extract the black grapes structures Compare with Ascorbic acid.

\section{REFERENCES}

[1] A.A.C.C., 2000. Approved Methods of American Assoiation of Cereal Chemists .10th Ed.St .Paul , Minnesota .U.S.A.

[2] A.O.A.C., 2005. Official Methods of Analysis of the Association of Official Analytical Chemists.18 th Ed .Gaithersburg, Maryland, U.S.A. 
[3] Alberto, Mn, R., A.R.C. Matias and M.C. Manca De Nadra, 2006. Antimicrobial effect of polyphenols from apple skins on human bacterial pathogens. Biotechnology, 19(3): 0717-3458.

[4] Al-samraee, A.M.M., 2011. Extraction of some phenolic compounds from grape seeds Shaddasodda, bedha and waste of grape juice and studying antimicrobial and antioxidants activities. Baghdad, Iraq: Agriculture College, Baghdad University.

[5] Aviram, M., 2004. Flavonoids-rich nutrients with potent antioxidant activity prevent atherosclerosis development: the licorice example. Int. Congr. Ser., 1262: 320-327.

[6] Ayoola, G.A., S.S. Ipav, M.O. Sofidiya, A.A. Adepoju-Beello, H.A. Coker and T.O. Odugbemi, 2008. International Journal of Health Research, 1(2): 87-93.

[7] Bagchi, D., M. Bagchi, S. Stohs, S.D. Ray, C.K. Sen and H.G. Preuss, 2002. Cellular protection with proanthocyanidins derived from grape seeds. Ann N.Y. Acad. Sci., 957: 260-270.

[8] Bayadar, N.G., G. Ozkan and O. Sagdic. 2004. Total phenolic contents and antibacterial activities of grapes (Vitisvinifera L.) extracts. Food Control, 15(5): 335-339.

[9] Benzie, I.F. and J.J. Strain, 1996. The ferric reducing ability of plasma (FRAP) as a measure of antioxidant power: the FRAP assay. Anal. Biochem., 239: 7076.

[10] Bors, W., C. Michal and K. Stettmaier, 1997. Antioxidant Effects of Flavonoids .mini-review, ISO press, Neuherberg, Germany.

[11] Broadhurst, R.B., W.T. Jones, 1978. Analysis of condensed tannins using acidified vanillin, J. Sci. Food Agric., 29: 788-794.

[12] Delaly, Basil Kamel, Sadiqhasn, 1987. Analysis of food. Ministry of higher education and scientific research. College of agriculture. University of Mosul.

[13] Faria, A., C. Calhau, V. Freitas and N. Mateus, 2006. Procyanidins as antioxidants and tumor cell growth modulators. J Agric Food Chem., 54: $2392-2397$.

[14] Hergert, H.L. and E.T. Kurth, 1953. The isolation and properties of catecol from white fir bark. Org. Chem., pp: 521.

[15] Igbal, M., Y. Okazaki and S. Okado, 2009. Cur cumin attenuates oxidative damage in animals treated with renal carcinogens ferric nitirilotri acetate: implication for cancer prevention. mol. cell. Biochemistry.dol:10.1007/s1010-008-994.z.

[16] Jayaprakasha, G.K., T. Selvi and K.K. Sakaria, 2003. Antibacterial and antioxidant activities of grape (Vitisvinifera) seed extracts. Food Research International, 36(2): 117-122.

[17] Kuppusamy, K., K. Panneerselvam and P. Viswanathan, 2008. Antioxidant efficacy of flavonoid-rich fraction from Spermacocehispida in hyperlipidemicrats. J. Appl. Biomed., 6(1214- 0287): 165-176.

[18] Martin, P.M. and E. Castanas, 2000. Potent inhibitory action of red wine polyphenols on human breast cancer cells. J Cell Biochem., 78: 429-441.

[19] Salih N.M., AL-Janabi, A.M. Mahmed AL-Samraee and W.S. Ulaiwi, 2013. The Effects of Squeezed Grapes Residue on the Preservation of Stored Fried Potato Chips. Pak. J. Chem. 3(1):1-4, ISSN (Print): 2220-2625. ISSN (Online): 2222-307X.

[20] Oliver chin, C.Y.B., 2008. Phytochemical composition of nuts. Asiapac J. Clin. Nut., 17(51): 329-332.

[21] Pantelidis, G.E., M. Vasilakakis, G.A. Manganaeies and G. Diamantidis, 2007. Antioxidant capacity. Phenol, anthocyanin and ascorbic acid content in raspberries, black berries, red currents, goos currant and cornelian cheerier. food chem., 102: 777-783.

[22] Pekic, B., V. Kovac, E. Alonso and E. Revilla, 1998. Study of the extraction of proanthocyanidins from grape seed. Food Chemistry, 61(1, 2): 201-206.

[23] Qian, H. and V. Nihorimbere, 2004. Antioxidant power of phytochemicals from Psidiumguajava leaf. J Zhejiang Univ Sci., 5: 676-683.Cited from (Sub ku et al., 2007).

[24] Rixan, R.A., D.Y. Xie and S.B. Sharma, 2005. Proanthocyandin final fantail in flavonoid research, New phytal, 165: 9-28.

[25] Rao, K.S., N.K. Keshar and K.B.V.V.J. Ravi, 2012. Medicinal plants Research, 6(3): 439-448.

[26] Rinaldo, D. et al., 2010. Determination of catechindiastereomers from the leaves of Byrsonima species using chiral HPLC-PAD-CD. (726-33 ed.).: Chirality 22(8).

[27] Shimada, K., K. Fujikawa, K. Yahana, T. Nakamura, 1992. Ant oxidative properties of xanthan on the ant oxidation of soybean oil in cycoldextrin emulsion. J. Agric. Food chem., 210: 945-948.

[28] Su, M.S., Y.T. Shyu and P.J. Chein, 2008. Antioxidant activities of citrus herbal product extracts, Food Chem., 111: 892-896.

[29] Sudheesh, S. and N.R. Vijayalakshmi, 2005. Flavonoids from punicagranatum-potenialantiperoxidative agents. Fitoterapia, 76: 181. 